\title{
Trophic Activities of Herons (Family: Ardeidae) in the Coastal Wetland in Buenavista, La Guajira (Colombia)
}

\author{
Geomar Molina-Bolívar*, Oscar Aldana-Ardila and Iris Jimenez-Pitre \\ BIEMARC, Universidad de La Guajira, Riohacha, Colombia; \\ iajimenez@uniguajira.edu.co, oaldana@uniguajira.edu.co,gmolina@uniguajira.edu.co
}

\begin{abstract}
Objective: This investigation had as objective to describe the tropic activities of the heron family Ardeidae) in units of Vegetation and Environment (EVU) of the coastal wetland Buenavista (CBH), La Guajira (Colombia). Methods: The CBH was divided into four sampling stations and five EVU's: beach (B), aquatic vegetation (VA), quagmire (Q), sand bank (SB) and open water (WO). The observations were carried out through censuses in points 25 fixed radio m., during $30 \mathrm{~min}$. Findings: 340 individuals were sighted, of which the majority is found in the $Q$ by the conditions of the place for food. The $71 \%$ of the individuals were found foraging, a fact that is given when the bird enters its peak or more than half on the substrate in search of food and $29 \%$ feeding activity; it is considered that the bird captures with his beak the dam and engullirla achieved. Application: The diversity of the herons was low, it was determined that the abundance of some species is due to the resources that offers this habitat and anthropogenic activities.
\end{abstract}

Keywords: Activities Food Webs, Coastal Wetland in Buenavista, Herons, Units of Vegetation and Environment

\section{Introduction}

Aquatic birds are an ecological indicator to evaluate the quality of coastal wetlands. In these natural habitats has been decreased biodiversity, mainly by shocks of anthro-

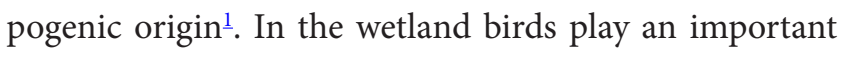
ecological role due to participating in links in the food web and nutrient cycling 2 . The herons are biological species with a significant number of Colombian biodiversity affected by habitat destruction and transformation ${ }^{\underline{3}}$ on the other hand, the family Ardeidae is constituted by 66 species, of which in Colombia have been recorded about $35 \%$, and in the coastal wetlands of the Guajira Peninsula, including the Coastal Wetland Buenavista $(\mathrm{CBH})$ have been reported in the $60 \%$ of the species reported in the country ${ }^{4}$. This taxonomic group is important because they are part of one of the faunal components of the coastalmarine ecosystems $2,4,5$.

Conservation strategies in tropical regions are conceived with the perception to prevent the loss of the diversity caused by the disappearance of habitat where the species with some ecological interest ${ }^{6}$. The choice of an area to protect is justified by the presence of threatened species, or regions with a high diversity of species such as are the case of the tropical forests, or by the presence of numerous endemic species. Another methodological approach for the selection of these areas is the formulation of biological indicators of species richness ${ }^{6}$. Such

${ }^{*}$ Author for correspondence 
is the case that in $\mathrm{CBH}$ is counted with the presence of Egretta rufescens which is one of the herons that is in the category of threatened. Various authors agree that the ornithological research have focused on the study of the terrestrial and have had little interest in those living in coastal wetlands, mainly ${ }^{4,7}$. The herons as the majority of the birds are good indicators of the biological quality of terrestrial and aquatic organisms, especially because they are tolerant to human presence, favoring its observation ${ }^{6}$. Wetlands are ecosystems with geomorphologic and hydrological conditions where the accumulation of water temporarily or permanently gives rise to a characteristic type of soil and/or biological species ${ }^{-}$. In the Guajira Peninsula, many of these bodies of water are increasing signs of deterioration in its structural and functional attributes due to overexploitation, fill, construction of civil works, water pollution, deforestation of the water rounds, and conversion of land for agriculture, erosion and fragmentation of the water system?

The $\mathrm{CBH}$ is characterized for being a place of passage and residence of various species of birds, among which stand out the water. In addition, this is an important area for the conservation of the coastal wetland complex of $\mathrm{La}$ Guajira. This habitat is not exempt to processes of deterioration by factors such as the settlements. Such is the case of four indigenous communities that inhabit its surroundings; which make extraction of timber and artisanal fishing, increase of indiscriminate hunting of resident and non-resident species with consequences in the increase in the marketing for use as pets. In addition, the increase in the activities of ecotourism is not planned; has influenced permanent disturbances and low rates of distribution, diversity and abundance of this taxonomic group ${ }^{6}$. The objective of this research was to determine the use of the habitat of the heron family Ardeidae, through the monitoring of their activities in the coastal wetland Buenavista $(\mathrm{CBH})$.

\section{Materials and Methods}

\subsection{Area of Study}

The $\mathrm{CBH}$ is part of the coastal wetland complex of $\mathrm{La}$ Guajira, a corridor of approximately $211 \mathrm{~km}$ in length and

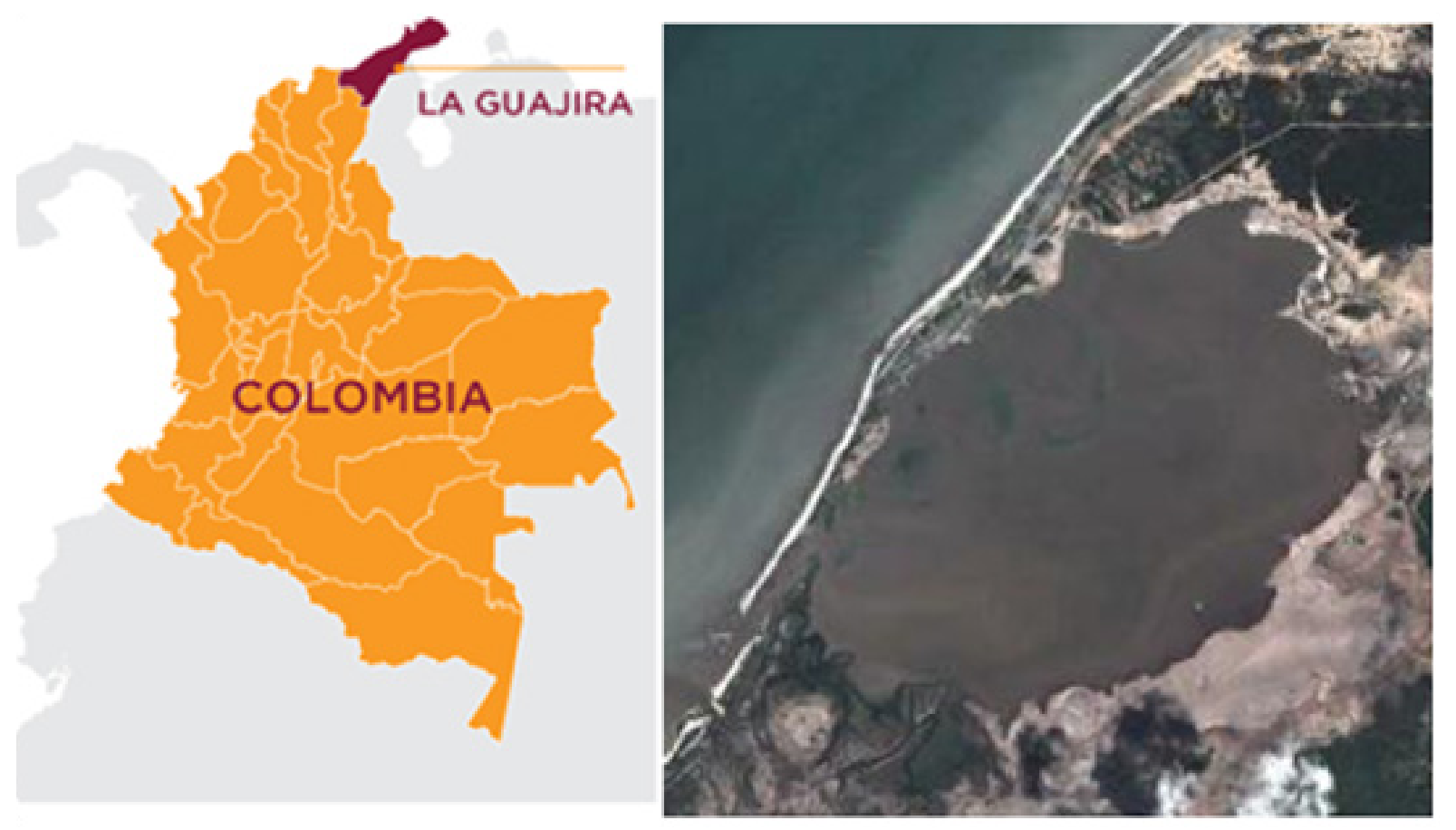

Figure 1. Area of study in Coastal Wetland Buenavista (CBH). 
$15 \mathrm{~km}$ wide along the coast. Located in the municipality of Manaure, North of the Cultural and tourist district of Riohacha. Between the coordinates $11^{\circ} 34^{\prime} 55^{\prime \prime} \mathrm{N}$ y $72^{\circ} 52^{\prime}$ $05^{\prime \prime}$ W. It has an area of approximately $10.40 \mathrm{~km}^{2}$ and is fed by the temporary streams: Ugarrasirro, Kejemahana, Totopajaja, Cucharamahana and Marueyo. Depending on the time of year this wetland can be connected with the sea and in winter seasons, usually receives the waters of the River Rancheria, because it is in the flood plain level. The mirror of water in breadth and depth decreases dramatically during dry periods. The waters are brackish and transparent; the $\mathrm{pH}$ ranges between 8.10 and 8.60. The average annual rainfall in the area of studies is between 5 and $150 \mathrm{~mm}$. In the area of influence of the wetland is the indigenous community La Raya; composed of 45 people, all belonging to the indigenous Wayuu community (Figure 1).

\subsection{Identification and Delimitation Units of Vegetation and Environment (EVU)}

The identification and delimitation of the environments are effected by Visual recognition in the field, taking into account the EVU's $\frac{10,11}{}$. For this study, the following EVU: Beach - B (H1); it is defined as the unconsolidated materials, such as sand or gravel, which is present in the interface shore wetland, Quagmire- $Q(H 2)$; are muddy areas that are protected from the direct action of the waves by sand bars. Occupy part of the mirror of water between the edge and the dry, Aquatic vegetation- $A V(H 3)$; is the area adjacent to the beach, Sand banks- $S B(H 4)$ are mounds of sand, which are arranged inside the mirror of water. Are formed when water levels in the wetlands with the help of the northeast trade winds? Usually host ictio fag as birds and serves as resting areas for other y Open Water - WO

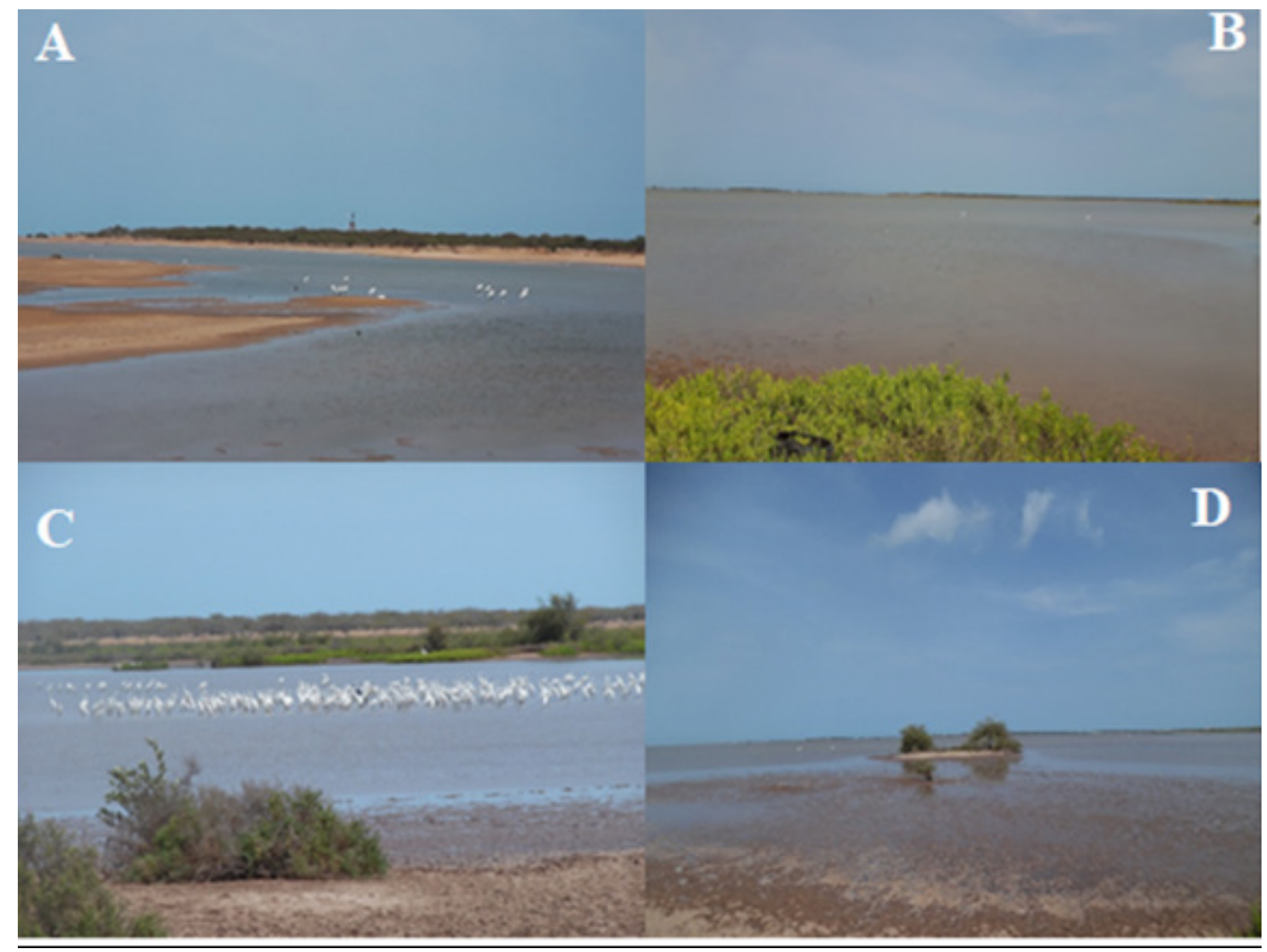

Figure 2. Sampling areas in the $\mathrm{CBH} . \mathrm{A}=$ Beach, $\mathrm{b}=$ aquatic vegetation, $\mathrm{C}=$ Quagmire, $\mathrm{D}=\mathrm{banks}$ of sand. 
(H5); are defined as water tanks that owe their formation to the waters of the rivers, lagoons, ponds or rain water, thanks to the fact that these serve as receptors hydrological.

To study the habitat use by birds in the $\mathrm{CBH}, 2$ were established monthly visits ( 3 days per visit), including from the 24 of October of 2012, until the 17 of November of 2013 , for a total of 22 days of sampling. The study area was divided into 4 sampling stations (S1... S4), each station has about $1 \mathrm{Ha}$, which was zoned by habitats, (H1... H6) as the dominant types of vegetation and the characteristics of the substrate ${ }^{12}$. At each station is defined two observation points of fixed radio separated by $200 \mathrm{~m}$., the radius used for each point was 25 meters, for a total of 8 points $\underline{13}$. Fixed radio spots were chosen taking into account, the ease of access, and the advantageous location for the observations, as well as for the photographic records, also took special care to minimize the alteration of the normal activities of birds by the presence of the observer. The distance between the points and its geographical coordinates were measured with GPS (Garmin Etrex 10). Each sampling station (S) was divided into the following sampling areas: H1: outside area of the wetland, located 6 meters from the edge of the wetland, its soil is characterized to have a great capacity of water infiltration, being of sandy-rocky, and does not possess any type of vegetation, this area is one of the access roads and communication between the different settlements of people living in the area of influence of the wetland, it is very frequent the transit of vehicles and people, H2: It is constituted of a soil type sandy, loam and saltpeter, has a sparse vegetation, composed of Batismaritima, grouped in small meadows, $\mathrm{H} 3$ : prairie with peaty without vegetation cover, H4: Body of water in the wetland type brackish, with swampy, with a depth of less than $25 \mathrm{~cm}$, H5: Sand Bar, with sandy soil, saltpeter, with presence of vegetation composed only by Juncus sp, on the periphery of the bar and H6: free water in the wetland, with a depth of more than $20 \mathrm{~cm}$ with swampy soil (Figure 2).

\subsection{Observation and Recognition of the Ardeidos}

The samplings were carried out by direct count in the area and in time defined, different methods were used on the collection of information, auditory and visual capture ${ }^{14}$. The observation time at each point was 30 minutes, taking into account that the observation time at each point was counted from arrival, as well all the morning had the start time of the 05:30 $\mathrm{h}$ and end-time 09:30 $\mathrm{h}$, sampling of the afternoon had the start time of the 14:00 $\mathrm{h}$ and endtime 17:00 $\mathrm{h}$. The activities were stratified in four samples in the morning and four in the afternoon. The tour was conducted in two directions, one with a home in point 1 of the 1 station and ending at Point 8 of the 4 station, in the first period of observation and the other with home in point 8 and 1 at the completion point, in the second period of observation. These tours are alternated during the three days of sampling. To move from one station to another is roamed free transects in a time of $20 \mathrm{~min}$ to record birds and thus avoid the ballot recount of the species 9 . For the identification of the observed species used the Field Guide to the Birds of Colombia ${ }^{14,15}$. The observations and data collection were carried out with binoculars (10×25) Celestron 71133 UpClose.

\subsection{Determination of the Diversity of Herons}

"Para determinar la composición de la familia Ardeidae se realizó una tabla para las especies registradas con su respectiva abundancia. La diversidad se determinó usando el índice de Margalef. Con respecto al esfuerzo de muestreo se realizó una curva de acumulación de especies para el número de visitas al humedal costero Buenavista, las cuales fueron calculadas de acuerdo con los estimadores JackKnife 1, JackKnife 2 y Bootstrap. Estos últimos permiten obtener una estimación del esfuerzo de muestreo mediante una aleatorización de las muestras. Para determinar la uniformidad en la distribución de la abundancia las especies se calculó el índice de Shannon - Wienery para calcular la diversidad, se utilizó la ecuación de Simpson". 


\section{Results and Discussion}

The feeding activity is given from the moment in which the bird captures with his beak the dam until it makes engullirla and foraging as the process that occurs when the bird enters its peak or more than half on the substrate in search of food of the 340 registered, $79 \%$ herons were foraging and the remaining birds feeding. For foraging the ardeidos have a high preference for the dry and wet. The presence of individuals in these EVU explains the abundance in these environments because of the availability of the substrate; mainly the muddy which favors at the time of forage (Figure 2) $4,16,17$.

Of the 340 individuals registered in this study, 30.50\% of the species of herons belong to the 23 species reported in the country ${ }^{4}$. These data corroborate the described those who believe that in the Caribbean region is a significant number of herons reported for Colombia $\frac{18,19}{\text {. }}$ Table 1 describes the abundance of species in the study area and Egretta thula with 197 individuals was the one that had the greatest abundance and species less abundant were the Ardea herodias and Egretta caerulea with an individual each.
The data reported in this study are relatively low compared to the 14 species of herons reported in several wetlands of the Guajira Peninsula, including the area of study ${ }^{20}$. These results may be a consequence of the development of industrialization activities near the wetland, siltation, soil erosion and deforestation, the low presence of herons can be an indicator of the environmental quality of the wetland. The areas where the ardeidos have been identified they become important sites to conserve to other taxonomic groups that are present in the majority of the country's wetlands $s^{21}$. The above-mentioned gives standing to assert that the Herons are easy to detect, identify, quickly and easily. In addition, has information about your growth or decline in populations $\underline{22}$.

The aim of this study in the $\mathrm{CBH}$ have a significant representation in accordance with the observations made are the populations of Egretta thula and Ardea alba. This representation is similar to other coastal habitats. In Table 2 we show the results of estimating indices of Margalef, and the Shannon-Wiener ${ }^{23}$. The diversity of the $\mathrm{CBH}$ is low as described by the Shannon-Wiener index ${ }^{24}$. The value of the Index of Margalef estimate indicates a low

Table 1. Species, absolute abundance and percentage of herons identified in the $\mathrm{CBH}$ during the study

\begin{tabular}{ccc}
\hline Species & Absolute abundance & $\%$ \\
\hline Ardea alba & 114 & 33,59 \\
Ardea herodias & 1 & 0,27 \\
Egretta caerulea & 1 & 0,27 \\
Egretta rufescens & 11 & 3,23 \\
Egretta thula & 197 & 57,94 \\
Egretta tricolor & 11 & 3,23 \\
Nyctanassa violácea & 5 & 1,47 \\
\hline Total & $\mathbf{3 4 0}$ & $\mathbf{1 0 0}$ \\
\hline
\end{tabular}


Table 2. Margalef indexes, the Shannon-Wiener estimated in the $\mathrm{CBH}$ during the study

\begin{tabular}{cc}
\hline Índice & Valor \\
\hline Índice de Margalef $\left(\mathrm{D}_{\mathrm{mg}}\right.$ & 0,80 \\
\hline Índice de Shannon - Wiener $\left(\mathrm{H}^{\prime}\right)$ & 0,78 \\
\hline
\end{tabular}

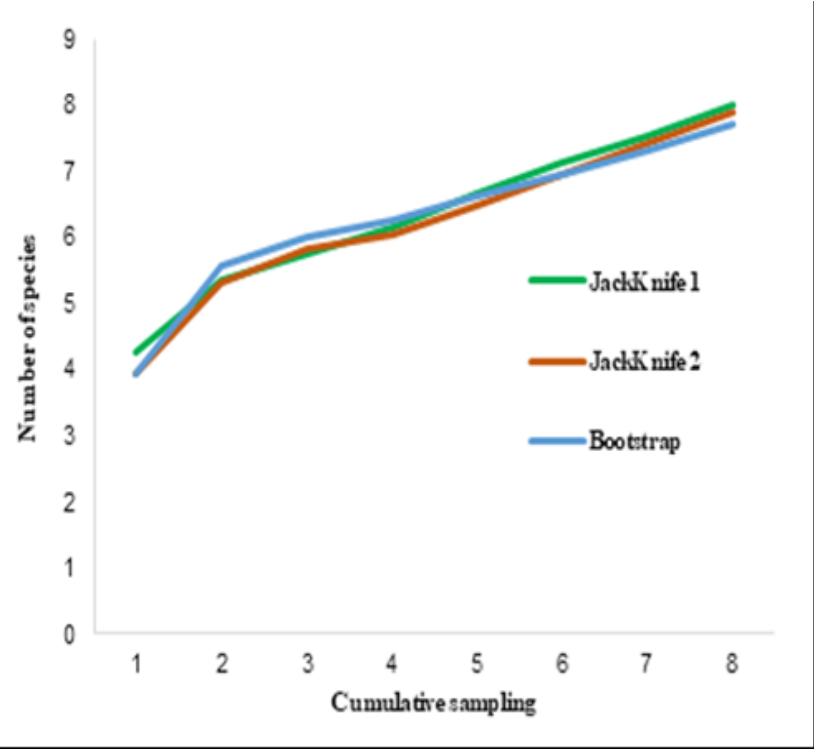

Figure 3. Species accumulation curve by random sampling in the study area.

diversity in the study area, can be associated with the non-uniform distribution of the heron family Ardeidae in the country 25 .

The species accumulation curve according to the indices calculated in the study area, which displays the number of species observed in function of the sampling effort required to observe them you can see how the curve has a tendency to grow even above the total species observed (Figure 3). This curve presented no trend toward the asymptote, which indicates that the number of species found on the site could increase with the increase in the number of samples ${ }^{4}$. The number of individuals in the EVU studied: Q, BS, B, WO, and AV는.

The EVU with greater abundance of the heron family Ardeidae was the Q, on the preferences of the herons

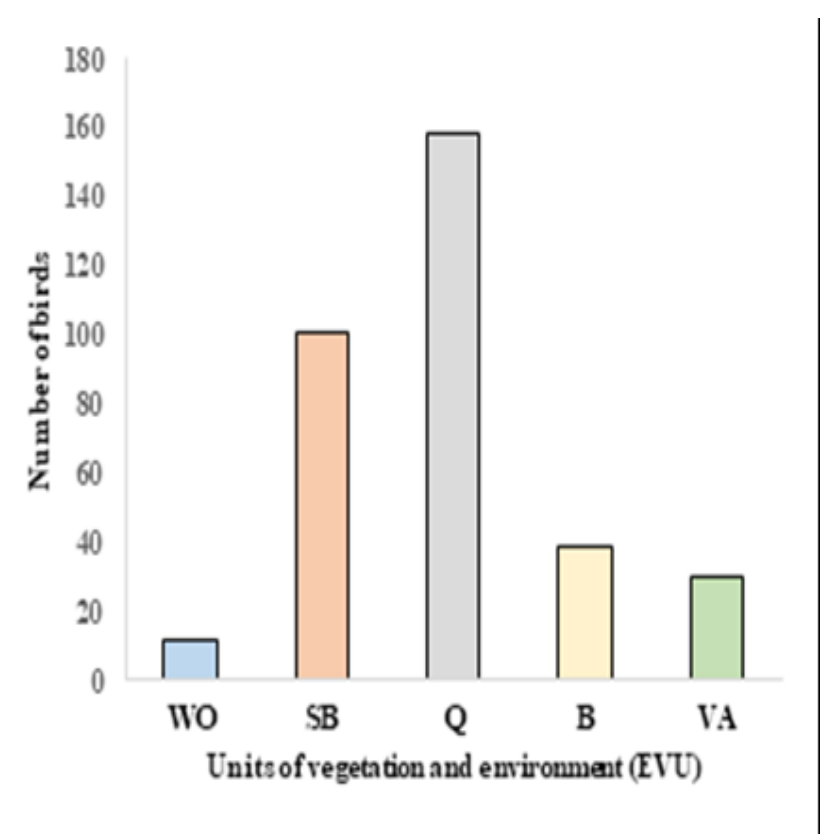

Figure 4. Number of birds per unit of vegetation and environments in the $\mathrm{CBH}$ during the study.

by the humid for the rest and foraging (Figure 4). The low number of individuals registered in the EVU: WO lies mainly in the average depth of the $\mathrm{CBH}(50 \mathrm{~cm})$, herons have a preference for shallow water or surface water (10 to $30 \mathrm{~cm}$ ); given that in these depths are the foods that make up your diet ${ }^{27}$. Despite the fact that it was found a low diversity of herons according to the indicators used, it was determined that there is an abundance of some of the species, this due to the resources provided by this habitat. Factors such as deforestation, buildings close to the wetlands and agriculture directly affect the $\mathrm{CBH}$, leading to a decline in the species of herons and the environmental quality of the wetland $28-30$.

\section{Conclusions}

In the $\mathrm{CBH}$ are 7 of the 23 species of herons reported for the country which corresponds to $30.5 \%$, this confirms that a significant number of herons reported for Colombia are in the Caribbean Region. The birds studied, have represented a significant amount of species characteristic of this habitat are reported populations of Egretta thula (197) and Ardea alba (114). Like similar coastal habitats, 
the family Ardeidae has a high representativeness compared to other families of the water mirror.

"Los valores de diversidad medidos con el índice de Shannon Wiener $\left(\mathrm{H}^{\prime}\right)$ arrojaron valores bajos, $\mathrm{H}^{\prime}=0,78$ lo cual nos muestra la diversidad baja del humedal con poca equitativita, probablemente como consecuencia de la intervención antrópica". With regard to the index of Margalef (DMG) that indicates a low diversity which is associated with the distribution of the family Ardeidae in the country $(\mathrm{Dmg}=0,80)$. The EVU with greater abundance of the heron family Ardeidae was Quagmire; (Q), which coincides with the preferences of the herons by the humid for the rest and the foraging. The low number of individuals registered in the EVU: WO lies in the fact that the average depth of the coastal wetland Buenavista is of $50 \mathrm{~cm}$; and the herons have a preference for wading through shallow waters in search of food, and on rare occasions they are seen in open waters and deep.

The ardeidos have a high preference for the dry and the wet for foraging, the high presence of individuals in these EVUs, coincides with the abundance of the herons in these environments that is due to the availability of the substrate, mainly the muddy, which delimits the abundance of birds to forage. The abundance of individuals of the family Ardeidae in the EVU - Quagmire (Q) can be explained by the presence of wetlands and soft sands which can encourage foraging, to feed and spend long periods of rest.

\section{References}

1. Bhadja P, Vaghela A. Study on avifaunal diversity from two freshwater reservoirs of Rajkot, Gujarat, India, International Journal of Research Zoology. 2013; 3(2):16-20.

2. Guía Ilustrada Aves Ca-ón del río Porce. Date accessed: 22/05/2015. Available at: https://www.epm.com.co/site/ home/sala-de-prensa/noticias-y-novedades/guias-ilustradas-del-canon-del-rio-porce.

3. Morales A, Ayerbe F. Ampliacion del rango de distribucion del chango llanero Quiscallus lugubris (ICTERIDAE) en Colombia, Revista del Instituto de Investigaciones Tropicales. 2006; 3:109-12.

4. Ruiz-Guerra C, Johnston-González R, Castillo Cortés Y, Cifuentes-Sarmiento D, Eusse, Estella FA. Atlas de aves playeras y otras aves acuáticas en la Costa Caribe colombiana. Asociación Calidris; 2008. p. 1-77.

5. Pierce RL, Gawlik DE. Wading bird foraging habitat selection in the florida everglades. 2008; 33(4):494-503.

6. Vazquez Regalad S. Análisis de patrones y caracterización de hábitat de Trogon spp y Euptilotissp aplicando sistemas de información geográfica en la Sierra Madre Occidental en el estado de Chihuahua. Tesis Biogeografía. Cuauthemoc: Instituto de Arquitectura Dise-o y Arte; 2015.

7. Arbeláez-Cortés E, Marín-Gómez O, Duque-Montoya, Ramirez Urrea L. Patrones de la composición de aves acuáticas en el río La Vieja, valle geográfico del río Cauca, Colombia, Acta Biológica Colombiana. 2014; 19(2):15566.

8. Flórez C, Estupi-án-Suárez L, Rojas C, Aponte C, Qui-ones M, Acevedo O. Identificación espacial de los sistemas de humedales continentales de Colombia, Biota Colombiana. 2016; 17(1):44-62.

9. Rincón Ruíz A, Echeverry Duque M, Pi-eros Quiceno A, Tapia Caicedo C, David Drews A, Arias Arévalo P. Valoración integral de la biodiversidad y sus servicios ecosistémicos Humboldt IdIdRBAv, editor. Bogota; 2014.

10. Ramos D, Castro V, Sánchez E. Caracterización de la vegetación a lo largo de una gradiente altitudinal en la comunidad de Cochahuayco, cuenca media del río Lurín, Lima, Ecología Aplicada. 2015; 14(1):11-25. Crossref. 11. Karlin M, Schneider C, Rufini S, Bernasconi J, Accietto R, Karlin U, et al. Caracterización florística de la Reserva Natural Militar 'Estancia La Calera, Nature and Conservation. 2014; 7(1):6-18. Crossref.

12. Vides Almonacid R. Observaciones sobre la utilización del hábitat y la diversidad de especies de aves en una laguna de la Puna Argentina, El Hornero. 1990; 13(02):117-28.

13. John Ralph C, Geoffrey R, Peter P, Martin TE, DeSante DF, Milá B. Manual de métodos de campo para el monitoreo de aves terrestres Albany. Pacific Southwest Research Station; 1996. p. 1-51.

14. Ure-a-Juárez P. Colonia mixta de aves acuáticas como objeto de conservación, Zona Protectora Tivives, Esparza, Costa Rica. Zeledonia. 2015; 19(2):43-53.

15. Renjifo LM, Gómez MF, Tibatá JV, Villarreal A, Kattan GH, Espine JD. Libro rojo de aves de Colombia Bogota: Pontificia Universidad Javeriana; 2013. p. 1-466.

16. Ruíz-Guerra C. Relación entre la dieta de siete especies de garzas (familia: Ardeidae) y la pesca artesanal en la zona deltaico estuarina del Río Sinú, caribe colombiano. Trabajo de grado para titulo de Master. Bogota: Pontificia Universidad Javeriana; 2016. PMid: 27466199, PMCid: PMC5291195.

17. Hilty J, Merenlender A. Faunal indicator taxa selection for monitoring ecosystem health, Biological Conservation. 2000; 92(2):185-97. Crossref. 
18. Cifuentes-Sarmiento Y, Castillo-Cortes LF. Censo Neotropical de Aves Acuáticas 2015, Calidris. 2016; 1:128.

19. Arteta B, Molina L. Avifauna de bosque seco subtropical presente en ocho localidades de la media guajira colombiana. Boletín Científico, Centro de Museos. Museo de Historia Natural. 2014; 18(2):125-37.

20. Marín-Mu-iz JL, Hernández Alarcón ME. Actividades de habitantes de Monte Gordo, Veracruz, como factor en cambios de, Rinderesu. 2016; 1(2):13-23.

21. Londo-o-Betancourth JC. Discusiones dobre la presencia de aves, rapaces, aves migratorias y aves bajo algun grado de amenaza en la ciudad de Pereira Risaralda, Universidad de Caldas. 2012; 36:134-64.

22. Franco-Maya AM, Bravo GA. Áreas importantes para la conservación de las aves en Colombia. Bogota: Bird Life / Conservación Internacional; 2005. p. 117-282.

23. Ramírez-Urrea L, Arbeláez-Cortés E, Marín-Gómez O, Duque-Montoya D. Patrones de la composición de aves acuáticas en el río La Vieja, valle geográfico del río Cauca, Colombia, Acta Biológica Colombiana. 2014; 19(1):155-66. Crossref.

24. Iannacone J, Alvari-o L. Diversidad y abundancia de comunidades zooplanctonicas del humedal pantanos de Villa Lima, Peru. 2007; 71(1):49-65.
25. Mugica Valdés L, Denis Ávila D, Acosta Cruz M, Jiménez Reyes A, Rodríguez Suárez A. Aves acuáticas de los humedales de Cuba Cuba: Editorial Científico-Técnica; 2000.

26. González-Oreja J, De La Fuente-Díaz-Ordaz A, Hernández-Santín L, Buzo-Franco D, Bonache-Regidor C. Evaluación de estimadores no paramétricos de la riqueza de especies. Un ejemplo con aves en áreas verdes de la ciudad de Puebla, México, Animal Biodiversity and Conservation. 2010; 33(1):31-45.

27. Domíguez J, De la Rosa CJ, Acu-a RB. Patrimonio emplumado de la Universidad del Norte. Guía de campo. Universidad del Norte; 2015. PMCid: PMC4306878.

28. Lorenzón R, Ronchi A, Beltzer A. Ecología trófica de la Garza blanca Ardea alba (Pelecaniformes: Ardeidae) en un humedal del río Paraná, Argentina. Cuadernos de Investigación UNED; 2012. p. 121-27.

29. Reinoso G, Villa F, Losada S. Plan manejo ambiental humedal el burro. Ibague: Universidad del Tolima; 2009.

30. Escalante I. Abundancia, uso de sustrato y forrajeo agrupado de aves limícolas en una playa lodosa intermareal. Universidad de Costa Rica, Escuela de Biología; 2008. p. $1-15$. 